\title{
« Evolution of the Zoroastrian Iconography and Temple Cults ». ANES (Ancient Near Eastern Studies, formerly Abr Nahrain), 38, (2001), pp. 160-177.
}

\section{Rémy Boucharlat}

\section{(2) OpenEdition}

1 Journals

\section{Édition électronique}

URL : http://journals.openedition.org/abstractairanica/34274

ISSN : 1961-960X

\section{Éditeur :}

CNRS (UMR 7528 Mondes iraniens et indiens), Éditions de l'IFRI

\section{Édition imprimée}

Date de publication : 15 mai 2003

ISSN : 0240-8910

\section{Référence électronique}

Rémy Boucharlat, « «Evolution of the Zoroastrian Iconography and Temple Cults ». ANES (Ancient Near Eastern Studies, formerly Abr Nahrain), 38, (2001), pp. 160-177. », Abstracta Iranica [En ligne], Volume 24 | 2003, document 49, mis en ligne le 05 janvier 2010, consulté le 25 septembre 2020. URL : http:// journals.openedition.org/abstractairanica/34274

Ce document a été généré automatiquement le 25 septembre 2020.

Tous droits réservés 


\title{
« Evolution of the Zoroastrian Iconography and Temple Cults ». ANES (Ancient Near Eastern Studies, formerly Abr Nahrain), 38, (2001), pp. 160-177.
}

\author{
Rémy Boucharlat
}

\begin{abstract}
Après bien d'autres, l'A. s'attaque à un difficile problème : confronter sources écrites et documents archéologiques se rapportant au zoroastrisme des époques préislamiques. Mais sa méthode rend l'entreprise vaine car, au lieu de faire la critique des uns et des autres, O.B. les considère le plus souvent au premier degré, utilise les uns lorsque les autres sont lacunaires, ou veut les réconcilier de force. Pour ce faire, il aligne les présupposés : admettant que selon un consensus (?) Zoroastre a vécu au début du $2^{\mathrm{e}}$ millénaire "somewhere in south western Siberia» (p.162), il tient pour acquis qu'il n'existe pas de temples jusqu'au $6^{\mathrm{e}} \mathrm{s}$.: les textes avestiques n'en parlent pas, et l'archéologie n'en fournit pas d'exemple; les Mèdes et les premiers Perses sont de bons zoroastriens, ils n'ont ni temples ni statues: les auteurs anciens le disent et l'on n'en connaît pas. La situation change vers 400 av.n.è., époque à laquelle, selon le témoignage de Bérose, sont introduits partout dans l'empire des monuments de culte. Le corpus des textes est sans doute fini (mais non pas celui des inscriptions), mais il mérite d'être encore scruté, celui de la documentation archéologique s'enrichit chaque année qui apporte son lot de données, même si, pour l'époque sassanide particulièrement, elles compliquent plus qu'elles ne clarifient la situation.
\end{abstract}


INDEX

Thèmes : 3.2.2. Pré-Achéménides et Achéménides

\section{AUTEURS}

RÉMY BOUCHARLAT

CNRS - Lyon 